\title{
Cerebral Venous Sinus Thrombosis in a 19 Year Old Female With Ulcerative Colitis: Long Term Follow-up and Review From the Literature
}

\author{
Anita Arsovska ${ }^{1}$ (D), Pietro Caliandro ${ }^{2}$, Valeria Caso ${ }^{3}$, Florin Scarlatescu ${ }^{4}$, \\ Marija Babunovska $^{1}$, Chiara Iakovelli ${ }^{5}$, Dennis Dietrich ${ }^{6}$ \\ ${ }^{1}$ University Clinic of Neurology, School of Medicine, "University Saint Cyril and Methodius”, Skopje, North Macedonia \\ ${ }^{2}$ Fondazione Policlinico Universitario Agostino Gemelli, Unità Operativa Complessa di Neurologia, Rome, Italy \\ ${ }^{3}$ Stroke Unit, Division of Cardiovascular Medicine, University of Perugia, Italy \\ ${ }^{4}$ Floreasca” Emergency Clinical Hospital-Neurology Clinic, Bucharest, Romania \\ ${ }^{5}$ Fondazione Don Carlo Gnocchi Onlus, Milan, Italy \\ ${ }^{6}$ Great Falls, MT and Department of Neurology, University of Washington, USA
}

ABSTRACT:

BACKGROUND: Cerebral venous sinus thrombosis is a rare complication of ulcerative colitis.

CASE PRESENTATion: We present a case report of a 19-year-old female patient with ulcerative colitis, who developed superior sagittal sinus thrombosis with haemorrhagic transformation. Despite the initial treatment with anticoagulant therapy, the patient became comatose, with symptomatic epileptic seizures and compromised cardiorespiratory function. She was transferred to the ICU and put on life-support for 3 weeks. She gradually improved and was discharged on low-molecular weight heparin and antiepileptic therapy. Oral anticoagulant therapy with warfarin was started 6 months later, when the subsequent D-dimers normalized. In the follow-up period, the patient experienced another series of symptomatic epileptic seizures and poorly regulated INRs. Therefore, antiepileptic and anticoagulation therapies were changed to oxcarbazepine and rivaroxaban.

Conclusion: Physicians should be aware that treatment of cerebral venous sinus thrombosis with haemorrhagic transformation in a patient with ulcerative colitis is very challenging and demanding. These patients need to be closely monitored for possible complications that might arise due to the concomitant presence of both diseases and possible drug interactions.

KEYWORDS: cerebral sinus venous thrombosis, ulcerative colitis, "thunderclap" headache, symptomatic epilepsy, anticoagulation

\section{SAŽETAK:}

UvoD: Tromboza vena sinusa mozga je rijetka komplikacija ulceroznog kolitisa.

Prikaz slučaja: Prikazujemo slučaj 19-godišnje bolesnice s ulceroznim kolitisom koja je razvila superiornu trombozu sagitalnog sinusa s hemoragičnom transformacijom. Unatoč početnom liječenju antikoagulantnom terapijom, pacijent je postao komatozan, sa simptomatskim epileptičkim napadajima i kompromitiranom kardiorespiratornom funkcijom. Pacijentica je prebačena na jedinciu intenzivnog liječenja tijekom naredna 3 tjedna. Postupno se poboljšavala uz terapiju heparina niske molekularne mase i antiepileptičku terapiju. Oralna antikoagulantna terapija s varfarinom započela je 6 mjeseci kasnije, kada su se sljedeći D-dimeri normalizirali. U razdoblju praćenja pacijent je doživio niz simptomatskih epileptičkih napadaja i slabo reguliranih INR-ova. Stoga su antiepileptička i antikoagulacijska terapija promijenjene u okskarbazepin i rivaroksaban.

ZAKLJUČAK: Liječnici trebaju biti svjesni da je liječenje cerebralne venske sinusne tromboze s hemoragičnom transformacijom u bolesnika s ulceroznim kolitisom vrlo izazovno i zahtjevno. Te bolesnike treba pomno pratiti zbog mogućih komplikacija koje bi mogle nastati zbog istodobne prisutnosti bolesti i mogućih interakcija lijekova.

KLJUČNE RIJEČI: cerebralna tromboza venskih sinusa, ulcerozni kolitis, glavobolja, simptomatska epilepsija, antikoagulacija

\section{OPEN ACCESS \\ Correspondence:}

Anita Arsovksa MD PhD anita70mk@yahoo.com orcid.org/0000-0003-1927-9614

This article was submitted to RAD CASA - Medical Sciences as the review article with case report

Conflict of Interest Statement: The authors declare that the research was conducted in the absence of any that could be construed as a potential conflict of interest.

Received: 15 June 2019 Accepted: 24 June 2019 Published: 22 July 2019

Citation:

Arsovska A, Caliandro P, Caso V et al. Cerebral Venous Sinus Thrombosis in a 19 Year Old Female With Ulcerative Colitis: Long Term Follow-up and Review From the Literature. RAD CASA Medical Sciences. 537=46-47 (2019): 48-54 DOI: $10.21857 / 94 \mathrm{kl} 4 \mathrm{cx} 2 \mathrm{jm}$

Copyright (C) 2019 Arsovska, Caliandro, Caso, Scarlatescu, Babunovska, Iakovelli and Dietrich.This is an open-access article distributed under the terms of the Creative Commons Attribution License (CC BY). The use, distribution or reproduction in other forums is permitted, provided the original author(s) and the copyright owners(s) are credited and that the original publication in this journal is cited, in accordance whit accepted ad acemic practice. No use, distribution or reproduction is permitted which does not comply with these terms. 


\section{INTRODUCTION}

Cerebral venous sinus thrombosis (CVST) is a relatively rare condition compared to arterial disease. The estimated incidence is $3-4 / 100.000$ in the adult population and up to 7/100.000 in children ${ }^{1}$. It is more common in women than in men, and young women (age 20-35 years old) are more frequently affected ${ }^{2}$. CVST can be caused by different conditions, such as collagen-vascular, infectious, structural, hypercoagulable states, hematological, hormonal, medication-related, and others (Table 1). Inflammatory bowel diseases, such as Crohn disease and ulcerative colitis (UC), have also been described as risk factors for CVST; it is suspected that hypercoagulable state occurring during the disease or the use of corticosteroids in the treatment could cause CVST.

\section{CASE PRESENTATION}

We present a case of a 19 year old female patient, who was admitted at the University Clinic of Neurology due to strong generalized "thunderclap" headache resistant to analgesics that was followed by acute onset of right sided hemiparesis and hemiparesthesiae 3 days before. On admission the patient was conscious, blood pressure was $115 / 70 \mathrm{mmHg}$, with right-sided hemiplegia and motor dysphasia. Urgent computed tomography (CT) of the brain showed a hypodensity involving the left parietal cortical and subcortical region with hyperdensities within the affected area, suspicious for venous infarction with haemorrhagic transformation due to thrombosis of the superior sagittal

Table 1. Conditions that may cause CVST

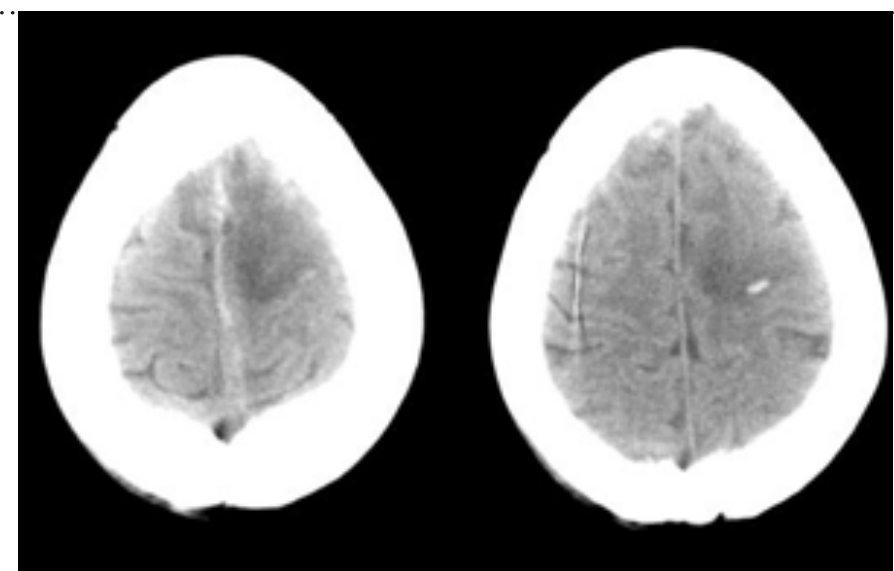

Figure 1. CT scan of a venous infarction with hemorrhagic transformation due to thrombosis of the superior sagittal sinus

sinus (Figure 1). She had been diagnosed with ulcerative colitis one year earlier and was on oral treatment with sulfasalazine and azathioprine. Therapy with low-molecular heparin (Clexane $2 \times 60 \mathrm{mg}$ ) was initiated.

Blood laboratory analysis showed increased levels of D-dimers $(12000 \mathrm{ng} / \mathrm{ml})$, erythrocyte sedimentation rate-ESR $(90 \mathrm{~mm} / \mathrm{h})$, CRP (136 mg/L) and decreased levels of RBC (2,51 10x12/L), albumin $27 \mathrm{~g} / \mathrm{L}$ and $\mathrm{Fe} 3,7 \mathrm{mmol} / \mathrm{l}$; other values were normal. Follow up CT of the brain two days after showed worsening of

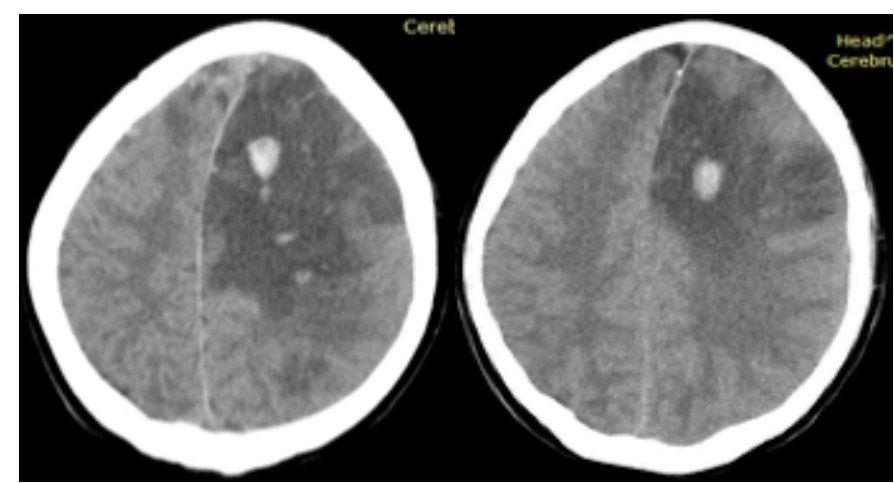

Figure 2. Control CT of the brain that showed massive venous infarction in the left parietal and left frontal region with compressive behavior towards the surrounding structures

\begin{tabular}{|c|c|c|c|c|c|c|c|}
\hline $\begin{array}{l}\text { Colagen- } \\
\text { vascular }\end{array}$ & Infectious & Structural & $\begin{array}{c}\text { Hypercoagulable } \\
\text { states }\end{array}$ & Hematological & $\begin{array}{l}\text { Medication- } \\
\text { related }\end{array}$ & Inflammatory & Others \\
\hline $\begin{array}{l}\text { Systemic lupus } \\
\text { erythematosus }\end{array}$ & Sinusitis & Head trauma & $\begin{array}{l}\text { Antiphospholipid } \\
\text { syndrome }\end{array}$ & $\begin{array}{c}\text { Paroxysmal } \\
\text { nocturnal } \\
\text { hemoglobinuria }\end{array}$ & $\begin{array}{c}\text { Oral } \\
\text { contraceptives }\end{array}$ & Crohn disease & Malignancies \\
\hline $\begin{array}{c}\text { Wegener } \\
\text { granulomatosis }\end{array}$ & & Surgery & $\begin{array}{l}\text { Protein S and C } \\
\text { deficiencies }\end{array}$ & $\begin{array}{c}\text { Thrombotic } \\
\text { thrombocytopenic } \\
\text { purpura }\end{array}$ & Corticosteroids & $\begin{array}{l}\text { Ulcerative } \\
\text { Colitis }\end{array}$ & Intracranial hypotension \\
\hline \multirow[t]{7}{*}{$\begin{array}{l}\text { Behçet } \\
\text { syndrome }\end{array}$} & & & $\begin{array}{l}\text { Antithrombin III } \\
\text { deficiency, }\end{array}$ & Polycythemia & $\begin{array}{c}\text { Epsilon- } \\
\text { aminocaproic } \\
\text { acid }\end{array}$ & & Lumbar puncture \\
\hline & & & $\begin{array}{l}\text { Lupus } \\
\text { anticoagulant, }\end{array}$ & Sickle cell disease & Thalidomide & & Hormonal \\
\hline & & & Leiden factor $\mathrm{V}$ & & Tamoxifen & & Hyperhomocysteinemia \\
\hline & & & $\begin{array}{l}\text { Pregnancy and } \\
\text { puerperium }\end{array}$ & & Erythropoietin & & Nephrotic syndrome \\
\hline & & & & & Phytoestrogens & & Dehydration \\
\hline & & & & & I-asparaginase & & Hepatic cirrhosis \\
\hline & & & & & Heparin & & $\begin{array}{l}\text { Sarcoidosis } \\
\text { Genetic }\end{array}$ \\
\hline
\end{tabular}


the previous finding, with venous infarction in the left parietal cortical and subcortical region, with dimensions $98 \mathrm{mmx} 56 \mathrm{~mm}$ and strong compressive behavior towards cerebral falx and left lateral ventricle, with haemorrhagic transformation with dimensions $16 \mathrm{mmx} 9 \mathrm{~mm}$ and several smaller punctate haemorrhagic changes (Figure 2). Antiedematous therapy with mannitol and steroids was administered.

During the hospitalization the patient had repeated focal complex motor symptomatic seizures with secondary generalization and antiepileptic therapy with carbamazepine was initiated.

Despite treatment, the patient worsened, she became comatose, with right hemiplegia. The fourth day the patient developed additional symptomatic focal complex motor seizures with secondary generalization and compromised cardiorespiratory function. She was transferred to the Intensive Care and Reanimation Unit and was intubated and ventilated. The 3 week course was complicated by aspiration pneumonia. Afterwards, she improved and was again transferred to the University Clinic of Neurology. On admission she was conscious, with bilaterally weakened vesicular breathing in the basal parts on auscultation, with bronchitic noises in the middle parts bilaterally. Neurological examination showed motor dysphasia and right sided hemiplegia with spastic features, hyperreflexia and positive Babinski sign.

Routine laboratory blood analysis showed moderate secondary anaemia with decreased levels of RBC, HGB and SeFe, elevated WBC and sedimentation, all other values were normal. Coagulation studies showed increased levels of D-dimer and therapy with low-molecular heparin (Clexane $2 \times 60 \mathrm{mg}$ ) was continued.

EEG showed groups of delta waves over the left temporo-occipital region.

Follow up CT after 10 weeks showed massive hypodense zone in the left parietal and left frontal region without compressive behavior towards the surrounding structures, i.e. venous infarction in the phase of reabsorption (Figure 3, A and B). Through this zone smaller hyperdense punctuate zones were seen, that could represent smaller haemorrhagic formations.

Genetic mutation investigations for cerebrovascular diseases showed heterozygote for A1298C mutation in the gene for MTHFR, heterozygote for mutation V34L in the gene for factor XIII, homozygote for mutation eNOS-786 T $>C$, heterozygote for mutation $455 \mathrm{G}>\mathrm{A}$ in the gene for B-fibrinogen and heterozygote for mutation eNOS G894T and LTA. Other tests (levels of antiphospholipid antibodies, protein $S$ and $C$, antithrombin III, lupus anticoagulant, and the Leiden factor V) were normal. The patients still had melena, so after gastroenterohepatologist and surgical consultations, proctocolectomy was recommended according to the severity of the disease and response to medical therapy. The patient was discharged after 2 weeks in a stable condition, with mRS score of 4 and treated with anticoagulation, gastroprotective, immunomodulatory and physical therapies. She came for regular visits every month, and was treated with low-molecular heparin (Clexane) for a period of 6 months (with

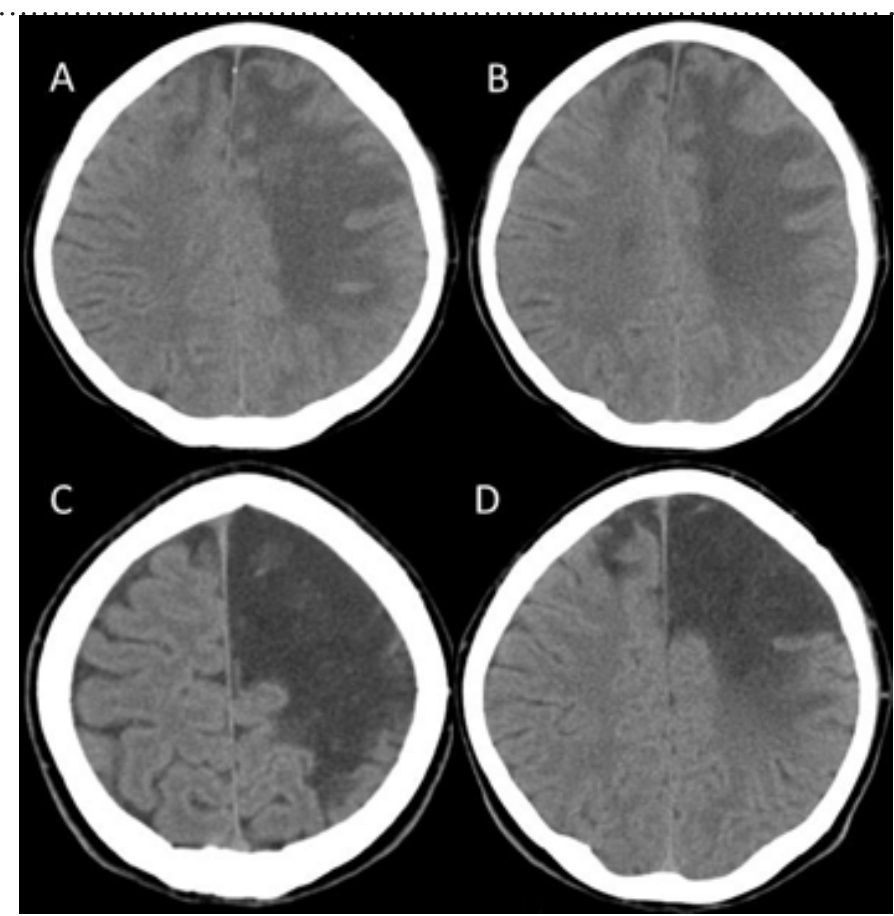

Figure 3. Control CT scan X weeks ( $A$ and $B$ ) and one year ( $C$ and $D)$ after the initial event of CVST, showing large postapoplectic sequela

gradually decreasing of the dose), due to melena. After 6 months the level of the D-dimer normalized. Melena resolved and she was switched to oral anticoagulant therapy with warfarin. Her neurological status slightly improved as well, she was able to walk with a stick on her own, and her speech also improved, with $\mathrm{mRS}$ of 3 . Subsequent CT scan showed large postapoplectic sequela (Figure 3, C and D). However, 14 months after the initial event of CVST, the patient experienced another series of focal complex motor seizures with secondary generalization. The dosage of carbamazepine was initially increased, but later switched to oxcarbazepine. Although the patient did not have any epileptic seizures in the following 6 months, she complained of transient side effects from oxcarbazepine (alopecia and skin rash on her back). Gradually, the side effects withdrew, and the patient did not experience them anymore. Nineteen months after the initial event, control INR showed poor regulation ${ }^{1,3}$, mostly due to green salad intake and its interaction with warfarin. Therefore, rivaroxaban of $15 \mathrm{mg}$ daily was recommended and warfarin was stopped.

\section{Discussion}

$\mathrm{UC}$ is a type of chronic inflammatory bowel disease (IBD) of unknown etiology that causes inflammation and ulcers in the the colon and rectum. It is a consequence of complex interaction of environmental factors and genetic susceptibility. UC may affect any age group, but most commonly appears in age groups between $15-30$ and 50-70 years. Approximately $40 \%$ of the patients have extra-intestinal manifestations in skin, joints, bones, lungs, blood, eyes, kidneys, liver, peripheral and central nervous system ${ }^{3}$. Patients with IBD have high thromboembolic risk, with an annual incidence varying between 0,5 to $6,7 \% \%^{4,5}$. Their risk for a thromboembolic event is increased 3-4 fold, compared to healthy controls $s^{4,6}$.

CVST has been reported as rare, but severe complication of UC, with the annual incidence ranging from $1.3 \%-7.5 \%{ }^{7,8}$. The clinical presentation of CVST, consisting of headaches, focal signs, seizures, or encephalopathy, and the sites of the venous occlusions are similar to the usual cerebral venous thrombosis. 
It can appear from 2 months to 17 years after the first attack of IBD. Sometimes, the diagnosis of IBD is established only when CVST occurs?.

Katsanos et al. have retrospectively reviewed 65 case reports from IBD patients complicated with CVST, published in the period from 1967-2012 ${ }^{10}$. Sources included MEDLINE and EMBASE and they included only papers written in English. We searched MEDLINE for case reports published in the period 2012-2019 and found 13 papers describing total of 17 cases with UC and CVST (Table 2).

Mahmoud et al. (2013) have described an 11 year old male patient with 3 months history of UC who presented as pseudotumor cerebri due to superior sagittal sinus thrombosis during an acute exacerbation of his colitis, that was successfully treated with heparin and then warfarin ${ }^{11}$.

Cojocary et al. (2014) published cerebrovascular complications in 9 patients with IBD (6 with Crohn's disease (CD) and 3 with UC, 4 of them during acute disease at admission ${ }^{12}$. Cerebrovascular complications were: CVT-7 cases (5 CD and 2 UC) and ischemic stroke-2 cases (1 CD and 1 UCC). Out of 7 cases with CVT 5 were superior sagittal sinus thrombosis (SSS), 2 SSS and transverse and sigmoid sinus thrombosis. Significantly high serum levels of homocysteine were observed in all patients. No correlation between high dose corticosteriods and its decrease, the activity of the
IBD, the duration of the disease, and the onset of cerebrovascular complications was found. Tendency to hypercoagulability, even in the inactive state of the IBD was observed. The outcome of cases was favorable, with the remission of symptoms in CVT cases and with residual motor deficits in ischemic stroke patients.

Shaik et al (2014) presented a pre-teenager with newly diagnosed UC and acute headache, altered mental status and bilateral lower extremity weakness, with thombosis in the vein of Galen and straight sinus, demonstrated on CT. Despite therapy with heparin, the patient clinically deteriorated and became unresponsive, and was therefore taken for endovascular treatment. A novel endovascular approach had been performed with combined use of Solitaire FR and Penumbra devices to enhance access to the straight sinus and to limit intraprocedural blood loss. The posttreatment CT demonstrated a decrease in hyperattenuation within the vein of Galen and straight sinus. The neurologic status improved within $24 \mathrm{~h}$. The patient was discharged home with a normal neurologic examination ${ }^{13}$.

Defillipis et al, 2015 reported 6 IBD patients with cerebral venous thrombosis, of which 4 had active $\mathrm{UC}^{14}$. The patients presented with hours to days of headache and were found to have venous thrombosis on imaging. All patients were treated with therapeutic anticoagulation. There were two deaths; one patient

Table 2. Case reports from patients with UC and CVST published in the period 2012-2019

\begin{tabular}{|c|c|c|c|c|c|c|c|c|c|}
\hline Author/year & Age & Gender & Active UC & UC treatment & Neurological symptoms & CVST location & Risk factors & $\begin{array}{c}\text { CVST } \\
\text { treatment }\end{array}$ & Outcome \\
\hline Mahmoud et al. 2013 & 11 & M & Yes & Prednizolon & $\begin{array}{l}\text { Headache, orbital pain, } \\
\text { photophobia, transient } \\
\text { blurred vision, vomiting }\end{array}$ & SSS & $\begin{array}{l}\text { Increment of } \\
\text { corticosteroid } \\
\text { dosage, relapse } \\
\text { of UC }\end{array}$ & $\begin{array}{l}\text { Heparin/Warfa } \\
\text { rine warfarin }\end{array}$ & $\begin{array}{l}\text { Completely } \\
\text { recovered }\end{array}$ \\
\hline Cojocaru et al, 2014 & 32 & M & Yes & $\begin{array}{l}\text { Sulfasalazine, } \\
\text { Prednizolone, }\end{array}$ & $\begin{array}{l}\text { Headache, generalized } \\
\text { convulsive seizures, } \\
\text { drowsiness, papiledema }\end{array}$ & $\begin{array}{l}\text { SSS, sigmoid S, } \\
\text { Transverse } \\
\text { sinus }\end{array}$ & $\begin{array}{l}\text { Increased serum } \\
\text { homocystein }\end{array}$ & LMWH & $\begin{array}{l}\text { Completely } \\
\text { recovered }\end{array}$ \\
\hline Shaikh et al, 2014 & $\begin{array}{l}\text { Preteena } \\
\text { ger }\end{array}$ & M & Yes & $\begin{array}{l}\text { Prednizone } / \mathrm{Me} \\
\text { salazine }\end{array}$ & $\begin{array}{l}\text { Headache, altered mental } \\
\text { status, bilateral lower } \\
\text { extremity weakness }\end{array}$ & $\begin{array}{l}\text { Vein of Galen, } \\
\text { Straight sinus }\end{array}$ & / & $\begin{array}{l}\text { Endovascular } \\
\text { (Solitaire FR } \\
\text { and } \\
\text { Penumbra)/He } \\
\text { parin/LMWH }\end{array}$ & $\begin{array}{l}\text { Completely } \\
\text { recovered }\end{array}$ \\
\hline DeFillipis et al, 2015 & 30 & M & Yes & Corticosterioids & / & / & / & LMWH & $\begin{array}{l}\text { Partially } \\
\text { recovered }\end{array}$ \\
\hline DeFillipis et al, 2015 & 12 & M & Yes & Corticosterioids & / & / & / & LMWH & $\begin{array}{l}\text { Completely } \\
\text { recovered }\end{array}$ \\
\hline DeFillipis et al, 2015 & 10 & M & Yes & Corticosteroids & / & / & / & Heparin drip & $\begin{array}{l}\text { Lethal } \\
\text { outcome }\end{array}$ \\
\hline DeFillipis et al, 2015 & 11 & $\mathrm{~F}$ & Yes & Corticosteroids & / & / & / & Heparin & $\begin{array}{l}\text { Lethal } \\
\text { outcome }\end{array}$ \\
\hline Calcagno et al, 2015 & 22 & $\mathrm{M}$ & Yes & $\begin{array}{l}\text { Mesalazine, } \\
\text { Prednizone }\end{array}$ & $\begin{array}{l}\text { Headache, speech } \\
\text { disturbance }\end{array}$ & $\begin{array}{l}\text { Sigmoid sinus, } \\
\text { superficial vein }\end{array}$ & / & $\begin{array}{l}\text { Heparin/Warfa } \\
\text { rin }\end{array}$ & $\begin{array}{l}\text { Completely } \\
\text { improved }\end{array}$ \\
\hline Meher et al, 2016 & 38 & $\mathrm{~F}$ & No & $\begin{array}{l}\text { Oral steroids, 5- } \\
\text { ASA, } \\
\text { Sulfasalazine }\end{array}$ & $\begin{array}{l}\text { Headache, nausea, vomiting, } \\
\text { blurred vision, papilloedema } \\
\text { photophobia, generalized } \\
\text { tonic-clonic seizure }\end{array}$ & $\begin{array}{l}\text { Sigmoid sinus, } \\
\text { Transverse } \\
\text { sinus }\end{array}$ & I & $\begin{array}{l}\text { LMWH/Warfar } \\
\text { in }\end{array}$ & $\begin{array}{l}\text { Completely } \\
\text { improved }\end{array}$ \\
\hline
\end{tabular}


became comatose and died despite anticoagulation while the other recovered well from the sinus thrombosis but died after a bowel perforation 3 weeks later. Five patients were being treated with corticosteroids at the time of the occurrence of CVT. Three patients were on anti-tumor necrosis factor inhibitors, including two on infliximab and one on certolizumab. The most common locations for CVT were sagittal sinus and transverse sinus, both occurring in three patients. However, four patients had multiple cerebral thrombi involving both deep cerebral and superficial cortical veins. One patient had the heterozygous C677T mutation in the MTHFR gene. Three patients had elevated factor VIII activity attributed to ongoing inflammation. All patients were treated with therapeutic anticoagulation and subsequently maintained on low molecular weight heparin or warfarin for 6 months or longer. Altogether two patients died, in which one became comatose and died despite anticoagulation. The patient had a progression of infarcts in the left hippocampus, right internal capsule, right thalamus and right medial temporal lobe, with increasing edema, mass effect and midline shift. The other patient recovered well following the sinus thrombosis with only mild residual right-sided weakness and was discharged on low molecular weight heparin. She was readmitted to another hospital 3 weeks later after experiencing a few days of abdominal pain, rectal bleeding and respiratory distress. The patient was found unresponsive by the emergency medical services. A head computed tomography $(\mathrm{CT})$ revealed no hemorrhage or evidence of ischemic stroke. The patient was found to have bowel perforation and underwent surgical intervention twice. She died from post-operative complications. Of the four patients who recovered, only one patient had any residual neurological deficits that were limited to trace right facial weakness, right-sided ataxia and mild sensory loss on the right hand and foot.

Calcagno et al, 2015 have described a case of a 22 year old male with UC in treatment with mesalazine and prednisone presenting with headache and speech disturbances ${ }^{15}$. A magnetic resonance imaging of the brain showed a left temporal hemorrhagic infarct with thrombosis of the ispilateral superficial vein and sigmoid venous sinus. No cause of thrombophilia was detected. Anticoagulation with heparin was started which was changed to oral anticoagulation with warfarin. The patient was discharged ten days after admission.

Meher at al, 2016 have reported a case of a 38-year-old female with a history of UC in remission who developed sudden onset headache, blurring of vision and seizures ${ }^{16}$. Subsequent diagnosis of cerebral venous sinus thrombosis (transverse and sigmoid sinus) was made with MRI venography and treated with low molecular weight heparin with complete resolution of symptoms.

Various mechanisms have been proposed as possible explanations for thrombosis in UC, such as hypercoagulation (elevated FVIII, fibrinogen, decrease in antithrombin, protein $S$ and protein $C$ ), hypofibrinolysis [elevated PAI-1 and lipoprotein (a)], platelet abnormalities, endothelial dysfunction (increased von Willebrand factor) and immunological abnormalities (antiphosphlipid antibodies) ${ }^{17,18}$. It has been suggested that the interaction between the coagulation cascade in the body and cytokine mediators of chronic inflammation and also the inflammatory process can itself activate the coagulation cascade ${ }^{18}$. Beside inflammation, the drugs used in the treatment (corticosteroids and sulfonamides) contribute to the thrombophilic tendency ${ }^{17,19}$. Some authors suggest that the majority of thrombotic events occur during the active phase of disease, however, others disagree. For example, Kristensen et al., reported a significant direct association of disease activity of IBD with increased risk of morbidity and mortality $^{20}$, while Katsanos et al., reported the presence of CVST in the active phase in $78.4 \%$ and in the inactive phase of the disease in $21.6 \%{ }^{21}$.

Risk factors and concomitant causes of CVST were systematically searched for in our patient. We found hypercoagulable state in our patient, with increased D-dimer levels. Also, biologic markers of inflammation such as elevated leukocyte count and $\mathrm{CRP}$ were registered and the patient was in an active phase of her UC (with continuous bleeding).

Genetic mutation investigations for cerebrovascular diseases showed (among other mutations), a heterozygote for A1298C mutation in the gene for methylenetetrahydrofolate reductase (MTHFR). Reports from the literature have also shown defective activity of MTHFR among patients with UC, which is linked to folate and vitamin $\mathrm{B}_{12}$ deficiency and causes hyperhomocysteinemia-related thrombosis ${ }^{22}$. Data from the literature have shown that patients with UC have more frequently lower circulating protein $S$ levels than normal controls ${ }^{23,24}$ and reduced levels of antithrombin III. But, in more than $50 \%$ of the patients with UC, no predisposing factor can be found ${ }^{25}$. The values of protein $\mathrm{C}, \mathrm{S}$ and antithrombin III in our patient were in normal range. The first-line treatment for CVST is adjusted-dose unfractionated heparin or low-molecular-weight heparin (LMWH), but its risks should be carefully weighed in light of possible hemorrhagic complications ${ }^{26}$. When the patient is relatively stable, oral anticoagulant therapy with warfarin is continued with an INR target 2-3 ${ }^{27}$. Steroids reduce the intracerebral edema and are also indicated in the active cases of ulcerative colitis ${ }^{28}$. Our patient had an active form of UC with constant bleeding from the gastrointestinal tract. Despite this fact, therapy with LMWH was initiated, as well as antiedematous therapy with mannitol and steroids. But, the patient's neurologic and physical condition gradually worsened and she had to be put on life-support for a period of 3 weeks. Her condition stabilized after this period and she became conscious, able to breathe on her own. Therapy with LMWH continued for a period of 6 months because she has had a hypercoagulable state. After the UC went into remission and 
bleeding had stopped, we were able to switch her on oral anticoagulant therapy with warfarin with satisfactory level of INR. She has continued with oral anticoagulant therapy in the following period, without any side effects. However, when we encountered difficulty regulating the INR, with a possible risk for recurrent thrombosis, we made a choice to stop warfarin and introduce rivaroxaban. We searched MEDLINE for similar cases, and only found one case report, where rivaroxaban was prescribed to a 17 years old female with a CVST and Crohn's disease ${ }^{29}$. There were also other case reports regarding administration of rivaroxaban in patients with CVST, but without known $\mathrm{UC}^{30,31,32}$.

Another problem that we have encountered was the recurrence of late onset epileptic seizures. The study of Kalita et al. ${ }^{33}$ showed that up to $5,6 \%$ of their patients with CVST had late recurrence of seizures. Recent study by the VENOST Study Group ${ }^{34}$ showed that epileptic seizures had no effect on prognosis of CVST.

Overall, the prognosis is usually good, but a few cases were fatal 9,21 . There are recommendations for prophylaxis of thromboembolic phenomena (including CVST) in patients with IBD. The Canadian Gastroenterology Association ${ }^{35}$ and the British Society of Gastroenterology ${ }^{36}$ recommend pharmacological thrombopro- phylaxis in patients requiring hospitalization for moderate-severe IBD and without severe bleeding.

\section{CONCLUSION}

CVST is a devastating complication of IBD, especially, UC. This case report signifies the importance of considering the diagnosis of CVST in a case of IBD. Any sudden neurological symptoms such as headache, hemiparesis and seizures in a patient with UC should initiate urgent diagnostics in order to prevent the complications of the disease. Physicians should be aware that treatment of cerebral venous sinus thrombosis with haemorrhagic transformation in a patient with ulcerative colitis is very challenging and demanding. These patients need to be closely monitored for eventual complications that might arise due to the concomitant presence of both diseases and possible drug interactions. Our patient with CVST associated to UC is the first case reported in literature treated with rivaroxaban because of INR poor regulation.

\section{AUTHOR CONTRIBUTIONS:}

All authors listed have made a substantial, direct and intellectual contribution to the work, and approved it for publication.

\section{LITERATURE:}

1. Daif A, Awada A, al-Rajeh S, et al. Cerebral venous thrombosis in adults. A study of 40 cases from Saudi Arabia. Stroke. 1995 Jul. 26(7):1193-5

2. Ameri A, Bousser MG. Cerebral venous thrombosis. Neurol Clin. 1992 Feb. 10(1):87-111.

3. Ozdil S, Akyuz F, Pinarbasi B, Demir K, Karaca C, Boztas G, et al. Ulcerative colitis: Analyses of 116 cases (do extraintestinal manifestations effect the time to catch remission?) Hepatogastroenterology. 2004;51:768-70.

4. Bernstein CN, Blanchard JF, Houston DS, Wajda A. The incidence of deep venous thrombosis and pulmonary embolism among patients with inflammatory bowel disease: A population-based cohort study. Thromb Haemost. 2001 Mar;85(3):430-4.

5. Papa A, Danese S, Grillo A, Gasbarrini G, Gasbarrini A. Review article: inherited thrombophilia in inflammatory bowel disease. Am J Gastroenterol. 2003 Jun;98(6):1247-51.

6. Miehsler W, Reinisch W, Valic E, Osterode W, Tillinger W, Feichtenschlager $\mathrm{T}$, et al. Is inflammatory bowel disease an independent and disease specific risk factor for thromboembolism? Gut 2004; 53 (4): 542-8.

7. Andersohn F, Waring M, Garbe E. Risk of ischemic stroke in patients with Crohn's disease: A population-based nested case-control study. Inflamm Bowel Dis. 2010;16(8):1387-92.

8. Koenigs KP, McPhedran P, Spiro HM. Thrombosis in inflammatory bowel disease. J Clin Gastroenterol. 1987 Dec;9(6):627-31.
9. Cognat E, Crassard I, Denier C, et al. Cerebral venous thrombosis in inflammatory bowel diseases: eight cases and literature review. Int J Stroke. 2011 Dec;6(6):487-92.

10. Katsanos AH, Katsanos KH, Kosmidou M, Giannopoulos S, Kyritsis AP, Tsianos EV.Cerebral sinus venous thrombosis in inflammatory bowel diseases. QJM. 2013 May;106(5):401-13. doi: 10.1093/qjmed/ hcs229. Epub 2012 Dec 12. Review.

11. Mahmoud Reza A, Firozeh H, Houman A, Mehri NS. Pseudotumor cerebri in a case of ulcerative colitis with sagittal sinus thrombosis. Iran J Pediatr. 2013 Feb;23(1):109-12.

12. Cojocaru IM, Cojocaru M, Sapira V, Ionescu A, Tacu N.Cerebrovascular complications in patients with inflammatory bowel disease. Rom J Intern Med. 2014 Jan-Mar;52(1):39-44.

13. Shaikh H, Pukenas BA, McIntosh A, Licht D, Hurst RW. Combined use of Solitaire FR and Penumbra devices for endovascular treatment of cerebralvenous sinus thrombosis in a child. BMJ Case Rep. 2014.

14. DeFilippis EM, Barfield E, Leifer D, Steinlauf A, Bosworth BP, Scherl EJ, Sockolow R. Cerebral venous thrombosis in inflammatory bowel disease. J Dig Dis. 2015 Feb;16(2):104-8.

15. Calcagno GP, Bagattini JC, Forster TA, Chiarella M, Cohen H. Intracranial sinus venous thrombosis in ulcerative colitis. Report of one case. Rev Med Chil. 2015 Apr;143(4):520-4.

16. Meher LK, Dalai SP, Panda S, Hui PK, Nayak S. Unusual Case of Cerebral Venous Sinus Thrombosis in Patient with Ulcerative Colitis in 
Remission. J Clin Diagn Res. 2016 May;10(5):OD35-6.

17. Danese S, Papa A, Saibeni S, Repici A, Malesci A, Vecchi M. Inflammation and coagulation in inflammatory bowel disease: The clot thickens. Am J Gastroenterol. 2007;102:174-86.

18. Stadnicki A. Involvement of coagulation and hemostasis in inflammatory bowel diseases. Curr Vasc Pharmacol. 2012;10(5):659-69.

19. Irving PM, Pasi KJ, Rampton DS. Thrombosis and inflammatory bowel disease. Clin Gastroenterol Hepatol 2005; 3: 617-28.

20. Kristensen SL, Ahlehoff O, Lindhardsen J, Erichsen R, Jensen GV, Torp-Pedersen C, et al. Disease activity in inflammatory bowel disease is associated with increased risk of myocardial infarction, stroke and cardiovascular death-a Danish nationwide cohort study. PLoS One. 2013;8(2):e56944.

21. Katsanos AH, Katsanos KH, Kosmidou M, Giannopoulos S, Kyritsis AP, Tsianos EV. Cerebral sinus venous thrombosis in inflammatory bowel diseases. Q J Med. 2013;106(5):401-13.

22. Mahmud N, Molloy A, McPartlin J, Corbally R, Whitehead AS, Scott JM, Weir DG. Increased prevalence of methylenetetrahydrofolate reductase C677T variant in patients with inflammatory bowel disease, and its clinical implications. Gut. 1999;45(3):389-394.

23. Koutroubakis IE, Sfiridaki A, Mouzas IA, Maladaki A, Kapsoritakis A, Roussomoustakaki M, Kouroumalis EA. et al. Resistance to activated protein $\mathrm{C}$ and low levels of free protein $\mathrm{S}$ in Greek patients with inflammatory bowel disease. Am J Gastroenterol. 2000;95(1):190-194.

24. Zezos P, Papaioannou G, Nikolaidis N, Vasiliadis T, Giouleme

O, Evgenidis N. Thrombophilic abnormalities of natural anticoagulants in patients with ulcerative colitis. Hepatogastroenterology. 2007;54(77):1417-1421.

25. Knot EA, ten Cate JW, Bruin T, Iburg AH, Tytgat GN. Antithrombin III metabolism in two colitis patients with acquired antithrombin III deficiency. Gastroenterology. 1985;89(2):421-425.

26. Solem CA, Loftus EV, Tremaine WJ, Sandborn WJ. Venous thromboembolism in inflammatory bowel disease. Am J Gastroenterol. 2004;99(1):97-101.
27. Lansberg MG, O’Donnell MJ, Khatri P, Lang ES, Nguyen-Huynh MN, Schwartz NE, et al. Antithrombotic and thrombolytic therapy for ischemic stroke: antithrombotic therapy and prevention of thrombosis: American College of Chest Physicians evidence-based clinical practice guidelines. CHEST Journal. 2012;141(2_suppl):e601S-36S.

28. Coutinho JM, Ferro JM, Canhão P, Barinagarrementeria F, Bousser MG, Stam J. ISCVT Investigators. Unfractionated or low-molecular weight heparin for the treatment of cerebral venous thrombosis. Stroke. 2010;41:2575-80.

29. Cerebral venous thrombosis in a patient with Crohn's disease. Cho YH, Chae MK, Cha JM, Lee JI, Joo KR, Shin HP, Baek IH, Jeon JW, Lim JU, Hong IT, Ki HJ, Kang JB. Intest Res. 2016 Jan;14(1):96-101. 30. Sugie M, Iizuka N, Shimizu Y, Ichikawa H. Cerebral Venous Thromboembolism in Antiphospholipid Syndrome Successfully Treated with the Combined Use of an Anti-Xa Inhibitor and Corticosteroid. Intern Med. 2015;54(23):3051-6.

31. Patel SI, Obeid H, Matti L, Ramakrishna H, Shamoun FE. Cerebral Venous Thrombosis: Current and Newer Anticoagulant Treatment Options. Neurologist. 2015 Nov;20(5):80-8.

32. Geisbüsch C, Richter D, Herweh C, Ringleb PA, Nagel S. Novel factor xa inhibitor for the treatment of cerebral venous and sinus thrombosis: first experience in 7 patients. Stroke. 2014 Aug;45(8):2469-71. 33. Kalita J, Chandra S, Misra KU. Significance of seizures in cerebral venous thrombosis. Seizure 21 (2012) 639-642 .

34. Duman T, Uluduz D, Midi I et al. VENOST Study Group. A Multicenter Study of 1144 Patients with Cerebral Venous Thrombosis: The VENOST Study. J Stroke Cerebrovasc Dis. 2017: S10523057(17)30178-7

35. Nguyen G, Bernstein C, Bitton A, Chan A, Griffiths A, Leontiadis G, et al. Consensus Statements on the Risk, Prevention and Treatment of Venous Thromboembolism in Inflammatory Bowel Disease: Canadian Association of Gastroenterology. Gastroenterol 2014; 146: 835-48. 36. Carter MJ, Lobo A, Travis S. Guidelines for the management of inflammatory bowel disease in adults. British Society of Gastroenterology. Gut 2004; 53 (Suppl V): v1-v16. 